\title{
Enhancing Atrazine Activity with Additions of Mineral and Vegetable Oils
}

\author{
L. Almodóvar-Vega and R. D. Ilnicli ${ }^{1}$
}

\section{INTRODUCTION}

Annual grasses often present a problem in corn culture. Such weeds invade corn fields in midsummer, usually after preemergence herbicides are no longer effective or because of failure to control them initially with preemergence herbicides.

It is well known that 2-chloro-4-ethylamino-6-isopropylamino-s-triazine (Atrazine) is a safe herbicide to use in corn when applied either as a preemergence or postemergence spray. Failure to control grasses successfully with postemergence sprays has offered a challenge to research workers to increase their effectiveness by use of spray adjuvants, either surfactants or oils.

It also is known that the postemergence activity of Atrazine can be increased by adding mineral oils to the spray at the rate of 1 to 2 gallons per acre. Little information is available concerning the effect of vegetable oils on Atrazine activity on grassy weed species such as crabgrass (Digitaria sanguinalis L.) and yellow foxtail (Setaria glauca L.).

\section{MATERIALS AND METHODS}

Two paraffinic oils were included in these studies. One of these was of low (No. 7) and the other was of medium (No. 11) viscosity. The vegetable oils tested in the experiments were from rape, peanut, sunflower, linseed, safflower, cotton, soybean, and corn. The so-called vegetable oils consisted of $1 / 8$ of vegetable oil plus $7 / 8$ of No. 11 oil.

A series of greenhouse experiments conducted during 1969 considered: 1, Different spray volumes; 2, various rates of Atrazine; and 3, Atrazine in combination with different rates of mineral or vegetable oils. Crabgrass and yellow foxtail were the test plant species; these usually were sprayed at the two-leaf stage of growth.

The weeds were sprayed with an endless belt sprayer calibrated to deliver the required amount of herbicide and herbicide mixtures, usually during the first week after weed emergence.

\section{RESULTS AND DISCUSSION}

The results obtained were: Atrazine without oils did not kill crabgrass. The gre $\mathbf{n}$ color of the grasses was intensified by Atrazine, as has been

\footnotetext{
1 Assistant Agronomist, Agricultural Experiment Station, Mayagüez Campus, University of Puerto Rico, Rio Piedras, P. R., and Research Professor in Weed Science, Department of Soils and Crops, Rutgers University, New Brunswick, N. J.
} 
observed in other plants. Oils alone did not kill the grassy weeds, although some yellowing occurred in some instances. No fertilizer was applied to the soil and it thus was difficult to ascertain exactly the degree of yellowing which could be attributed solely to the oils. Yellow foxtail was more susceptible to Atrazine either alone or combined with oils, especially with No. 11 oil. Atrazine alone at the rate of $1 \frac{1}{2} \mathrm{lb}$./A. also effected good control (75-84 percent). The three different spray volumes of 10,20 , and $40 \mathrm{gal} . / \mathrm{A}$. generally effected the same degree of weed control.

Field corn (Zea mays var. N. J. No. 9) was not affected by any of the herbicide treatments or combinations. Two experimental surfactants, AL209 and AL411A, also were evaluated at 1 percent v/v with Atrazine at the rate of $3 / 4 \mathrm{lb} . / \mathrm{A}$. These effected poor control (less than 64 percent); however, when combined with Atrazine at the rate of 11/2 lb./A., fair control (65-74 percent) of crabgrass was produced. At concentrations of $1 / 2$ or 2 percent $v / v$ the control was less effective than at 1 percent $v / v$.

Safflower oil produced very good grass control (85-94 percent) at $1 / 4$, $1 / 2$, or 1 gal./A. in combination with Atrazine at the rate of $3 / 4 \mathrm{lb}$./A. Linseed and cottonseed oils produced excellent control (95-100 percent) at the rate of $1 / 2$ gal./A. plus $3 / 4 \mathrm{lb}$. of Atrazine.

Soybean oil was the least effective of the group, although it produced fair control (65-74 percent) of crabgrass at the three rates used.

Rape oil effected very good control (85-94 percent) of crabgrass and yellow foxtail at the three rates evaluated in combination with $3 / 4 \mathrm{lb}$. of Atrazine. Peanut oil produced very good control (85-94 percent) at the rate of 1/2 and 1 gal./A. but was less effective at 1/4 gal./A. Corn and sunflower oils produced very good control (85-94 percent) at all rates evaluated. These oils were much more effective when the higher rate of Atrazine was used. All the oils tested produced excellent grass control (95-100 percent) when combined with 11/2 lb./A. of Atrazine.

In another set of experiments in which all the oils were evaluated at the same time using $1 / 2$ gal./A. of vegetable oils and $1 / 2$ and 1 gal./A. of mineral oils, sunflower and soybean were not effective when combined with $3 / 4 \mathrm{lb}$./A. of Atrazine. Both, however, gave good control (75-84 percent) with 11/2 lb./A. of Atrazine.

Poor weed control (less than 64 percent) resulted in nearly all instances when the spray applications were delayed one week, although Atrazine at the rate of $11 / 2 \mathrm{lb} . / \mathrm{A}$. with rape oil gave good control (75-84 percent). Linseed oil at 1/2 gal./A. and mineral oils (No. 7 and No. 11 oils) at 1 gal./A. gave fair control (65-74 percent).

\section{SUMMARY}

Greenhouse experiments were conducted during 1969 to evaluate the enhancement of Atrazine activity by the addition of mineral and vegetable 
oils. Two grassy weeds, crabgrass and yellow foxtail, were used as test species.

The results showed that grassy weeds may be controlled with lower rates of Atrazine by using non-phytotoxic oils as adjuvants. Differences in Atrazine enhancement were observed among the oils tested and the rates of application. Early postemergence applications (weeds at the one- to two-leaf stage of growth) resulted in better control than applications delayed 1 week.

\section{RESUMEN}

En el 1969 se llev6 a cabo una serie de experimentos en el invernadero para determinar si la eficacia del Atrazine puede aumentarse añadiéndole aceites de origen mineral y vegetal. Para las pruebas se usaron dos gramineas (Digitaria sanguinalis L. y Setaria glauca L.), yerbajos anuales que comúnmente surgen en las plantaciones de maíz.

Los resultados obtenidos demostraron que los yerbajos pueden controlarse con cantidades reducidas de Atrazine combinándolo con aceites no tóxicos al preparar la solución. Hubo diferencias en cuanto a la eficacia del yerbicida al usarse distintos aceites y en diversas proporciones. Las aspersiones postemergentes a temprana edad (cuando los yerbajos solo tenían una o dos hojas) dieron mejores resultados para el control de los yerbajos que las aspersiones tardías hechas una semana después. 